\author{
ANDREW S. CARRON \\ Brookings Institution
}

\title{
Financial Crises: Recent Experience in U.S. and International Markets
}

The threat of a "financial crisis" may have motivated the Federal Reserve Board's apparent decision to relax monetary policy earlier this year. Such crises have been a recurrent theme since the mid-1960s, although definition of the term and prediction of the event have proved equally elusive. Corporate bankruptcies, failures in the thrift industry, problems at regional banks, and near-defaults on loans to foreign borrowers have created new concerns about the resiliency of the financial structure. The concerns are especially great because of the linkages between the health of the financial system and the growth of real economic activity.

In this paper I propose to differentiate between the ebb and flow of the business cycle on the one hand, and events triggered by financial market weaknesses on the other. In that context, I evaluate recent experience in domestic and international financial markets. My conclusion is that the current episode qualifies as a full-fledged crisis of a magnitude comparable to the 1974-75 experience. The Federal Reserve is seen to play crucial roles both in the development and in the resolution of past and present crises.

\section{Definition}

Analysts have used the term "financial crisis" (or a variant such as "liquidity crisis") to describe a variety of phenomena differing primarily in the degree of distress that is implied. Hyman Minsky has emphasized

I thank Ralph C. Bryant and the Brookings Panel for helpful comments. I also thank Judith D. Kleinman for research assistance and Kathleen Elliott Yinug for secretarial assistance. The research on thrift institutions presented here was supported, in part, by a grant from the Federal Home Loan Bank Board. 
the potential instability of the credit system. ${ }^{1} \mathrm{He}$ has in mind a forced liquidation of assets, occasioned by an inability to raise cash through more conventional means, which precipitates a sharp drop in asset prices and leads inevitably to a depression. ${ }^{2}$

Allen Sinai and others describe a cyclical "crunch period" as a less severe but more common type of financial event. ${ }^{3}$ These are episodes that begin during an economic expansion with an intensifying squeeze on liquidity. Monetary policy is restrictive. The ensuing high level of interest rates or credit rationing causes businesses and consumers to curtail their spending plans, and eventually a recession ensues. Reduced demand then permits rates to fall, and the episode ends.

The important distinction between the Minsky and Sinai phenomena is the manner in which the stress is resolved through a shift of the burdens from the financial markets to the real sector. In the Minsky formulation, pressures increase until the financial markets break down, and this in turn triggers depression in the real sector. In a Sinai crunch, financial stringency is continuously transmitted to the real economy, so the recession occurs without sudden disruptions in financial markets and is consequently milder.

Financial crises, as the term is to be used here, differ from either the Minsky or Sinai phenomena. The former almost never occurs and the latter is observed during every period of tight money. Here I consider and characterize an important intermediate case. At any time, a borrower may confront a rise in the risk premium lenders demand for reasons related to the borrower's real economic position. In a financial crisis, by contrast, some borrowers face a premium arising from financial developments elsewhere that are unrelated to their own outlook. Such an excess premium can take the form of exceptionally high interest rates or of credit rationing that effectively precludes borrowing.

Borrowers confronting traditional risk premiums can be said to be paying the socially appropriate interest rate given their situation, whereas

1. See Charles P. Kindleberger, Manias, Panics, and Crashes: A History of Financial Crises (Basic Books, 1978), pp. 3-24.

2. Hyman P. Minsky, "A Theory of Systemic Fragility," in Edward I. Altman and Arnold W. Sametz, eds., Financial Crises: Institutions and Markets in a Fragile Environment (Wiley, 1977), pp. 139-40.

3. Allen Sinai, "Credit Crunches-An Analysis of the Postwar Experience," in Otto Eckstein, ed., Parameters and Policies in the U.S. Economy, Data Resources Series, vol. 2 (Amsterdam: North-Holland, 1976), pp. 244-74. 
borrowers faced with an excess premium are paying rates that reflect general financial disruptions but not their own economic prospects. Such effects can precipitate solvency and liquidity problems that originate with the excessive cost of funds. A firm in this position will reduce planned capital spending and output more than its real economic situation warrants. In turn, this will adversely affect employees and suppliers, spreading problems to other sectors. In the extreme, otherwise healthy firms could fail as bad news about unrelated firms raised borrowing costs and reduced economy-wide sales and output.

\section{PENN CENTRAL}

The bankruptcy of the Penn Central Transportation Company is a well-known case that can illuminate these distinctions. ${ }^{4}$ In June 1970 Penn Central had \$200 million in commercial paper outstanding. The company had just recorded a $\$ 63$ million first-quarter loss and its bank credit lines were exhausted. When a last-minute effort to secure government loan guarantees failed, Penn Central went into default.

What followed is subject to varying interpretations. Some consider the Penn Central episode to have been a serious crisis while others do not. ${ }^{5}$ A few companies, notably Chrysler Financial Corporation and Commercial Credit Corporation, were virtually unable to roll over maturing commercial paper. Total paper outstanding fell $\$ 7$ billion between May 1970 and year-end. Banks were able to take up some of the slack: total bank loans increased by $\$ 13$ billion over the period as jumbo certificates of deposit outstanding rose by $\$ 12$ billion in 1970:3.

In anticipation of ripple effects, the Federal Reserve had made known its willingness to lend to banks through the discount window, and rate ceilings were removed on short-term jumbo CDs. As the Penn Central situation unfolded, bank borrowings from the Federal Reserve climbed steadily from $\$ 748$ million in the week before the default to $\$ 1.8$ billion a month later. The markets having remained reasonably calm, discounts and advances declined to less than $\$ 700$ million by the end of the summer.

4. This example has been widely cited. See, for example, Thomas M. Timlen, "Commercial Paper-Penn Central and Others," in Altman and Sametz, eds., Financial Crises, pp. 220-25; and Albert M. Wojnilower, "The Central Roie of Credit Crunches in Recent Financial History," BPEA, 2:1980, pp. 292-94.

5. See Wojnilower, "Credit Crunches," p. 293; and Economic Report of the President, February 1971, p. 69. 
Thus the problems seem to have been confined to a relatively fewalbeit large-companies. Interest rates on commercial paper of nonfinancial corporations moved up a few basis points in July 1970 as other market rates drifted lower, but preexisting spreads were reestablished the following month. Rates on finance paper initially showed a somewhat larger bulge, but by the end of the year, normal spreads were being restored. The banks that took up the loan demand of corporations that had been foreclosed from the paper market were likewise unaffected: CD rates also fell continuously through the second half of 1970 , despite the lifting of regulation $Q$ ceilings and the presumed riskiness of the new loans. A fairly substantial shift in the composition of assets was accomplished with virtually no disruption.

The difficulties of Chrysler Financial, Commercial Credit, and others may be traced to conditions peculiar to those firms and not to the overall financial situation. Before the Penn Central default the market may not have adequately assessed their riskiness, while afterward the appropriate risk premiums were demanded. The 1969-70 period was not a serious crisis.

\section{OPEC I AND FRANKLIN NATIONAL BANK}

Some have suggested that the $1974-75$ period was a major crisis. ${ }^{6}$ The Arab oil embargo in the fall of 1973 had put severe strains on the economy. Rates on bank jumbo CDs jumped sharply in the first months of the embargo but then settled back to a normal spread over Treasury bills in the first quarter of 1974 (see table 1).

But then Franklin National Bank of New York, one of the nation's largest, failed in May 1974, followed by the Herstatt Bank failure in Cologne, Germany, and the problems of the Real Estate Investment Trusts connected with many banks. Renewed doubts about the safety of the banking system led to a large increase in rates on CDs relative to Treasury bills. The spread rose from an average of 45 basis points in the late 1960 s and early 1970 s to nearly 300 basis points by mid-1974, a level that has yet to be equaled. (The Treasury bill rate was itself rising during this period.) The spread peaked briefly at 470 basis points in July 1974 .

6. "'Are Credit Crunches Predictable?'” Economic Research (Goldman Sachs, September 1981), pp. 4-11; and Wojnilower, "Credit Crunches," pp. 296-99. 
Table 1. Interest Rate Differentials between Bank CDs and Treasury Bills, Selected Periods, 1965-79

Percentage points

\begin{tabular}{cccc}
\hline & & $\begin{array}{c}\text { Jumbo CD rate less } \\
\text { three-month Treasury } \\
\text { bill yield }\end{array}$ \\
\cline { 2 - 3 } Episode & Period or quarter & Mean & $\begin{array}{c}\text { Standard } \\
\text { deviation }\end{array}$ \\
\hline Penn Central & $1965: 1-1969: 4$ & 0.45 & 0.32 \\
& $1970: 1$ & 1.07 & $\ldots$ \\
2 & $1.00^{\mathrm{b}}$ & $\ldots$ \\
& 3 & 0.87 & $\ldots$ \\
Oil embargo & 4 & 0.57 & $\ldots$ \\
& $1971: 1-1973: 2$ & 0.45 & 0.19 \\
& $1973: 3$ & 1.72 & $\ldots$ \\
4 & 1.35 & $\ldots$ \\
& $1974: 1$ & 0.35 & $\ldots$ \\
& $1974: 2$ & & $\ldots$ \\
& 3 & 2.95 & $\ldots$ \\
& 4. & 2.99 & $\ldots .26$ \\
\hline
\end{tabular}

Source: Author's calculations based on Board of Governors of the Federal Reserve System, Banking and Monetary Statistics, 1941-1970 (1976) and Annual Statistical Digest, 1970-197.9 (1981).

a. Last month of quarter. The jumbo CD rate is the three-month discount rate for certificates of deposit in the secondary market converted to investment yield.

b. Rate ceiling removed June 1970 .

The conventional wisdom is that only the largest and most creditworthy banks were able to roll over maturing CDs, and that this inability to raise funds caused a reduction in new loan commitments and intensified the ensuing recession. Yet the volume of jumbo CDs outstanding rose by $\$ 76$ billion at a seasonally adjusted annual rate in $1974: 2$ and by $\$ 46$ billion in 1974:3, compared with much smaller amounts in the preceding quarters. Net new bank lending continued to be positive through 1974:4. As the shocks of the Franklin National collapse were beginning to be felt, the Federal Reserve was once again called upon to step in. Banks managed to retain deposits on their own, however, by offering higher premiums on jumbo CDs. Nearly all of the $\$ 2.1$ billion increase in discount-window borrowing between 1974:1 and 1974:3 went to Franklin 
National itself. Advances to Franklin National were $\$ 1.7$ billion on October 8, 1974, when that obligation was assumed by the Federal Deposit Insurance Corporation (FDIC). By year-end, total advances were well below the precrisis level.

The increased cost of funds to banks was passed through in the form of higher lending rates. The prime rate rose from $83 / 4$ percent before the Franklin National crisis to 12 percent shortly after, roughly paralleling the change in the $\mathrm{CD}$ rate. For the prime rate this level represented a record spread over Treasury yields that was surpassed only when credit controls were imposed in 1980.

Clearly the entire banking system did not become much riskier in those few months. Nor does it seem plausible that investors were underestimating the risks to that great an extent before mid-1974. Moreover, yields retreated and spreads narrowed rapidly within a year. The aberration appears to have arisen from events within the financial system, and has the characteristics of a serious crisis as defined here. Corporations whose borrowing was linked to the prime rate paid premiums that had more to do with perceived risks in the banking system than with themselves. And, although the duration of the crisis was brief, these were real costs that contributed to reduced earnings and curtailed capital spending.

A major financial disruption more severe than anything experienced in the last thirty-five years would seem to require not only the preconditions of a crisis, but also lack of confidence by investors bordering on panic and an inability or unwillingness by the central bank to intervene effectively. These further conditions seem unlikely to be satisfied. Markets remained orderly during the two episodes described above, as indicated by the continuing volume of transactions. Moreover, there was every indication that the Federal Reserve was prepared for the problems that arose.

\section{Present Financial Risks}

The current period clearly qualifies as at least a financial crunch of the sort described by Sinai. Economic expansion has ended with the application of tight monetary policy. High real interest rates have combined with lower levels of real demand to cause serious cash-flow problems for businesses in several sectors. 
The household sector has suffered declines in real income and a rise in unemployment. Spending has been curtailed, and loan repayments are beginning to lag. Although consumer loan delinquencies have remained level, recent experience with mortgage loans is less favorable. As of mid-1982, mortgage delinquencies as a share of loans outstanding were 60 percent above 1979 levels and foreclosures were up more than 40 percent. ${ }^{7}$ Interest income of financial corporations has been impaired somewhat as a result.

These trends have been cited as the incipience of a serious financial crisis. One cannot minimize the substantial dislocations that have occurred to corporations, households, and sovereign borrowers and, indirectly, to the banking system. Indeed, the repercussions on financial institutions may well represent the more serious set of problems.

The balance of this paper reviews conditions in several areas of the economy and argues that the financial system moved to the level of nascent crisis at some point in 1982. Evidence of crisis conditions are described and distinguished from other indicators of palpable, but nonfinancial, stress. The section concludes with a brief discussion of the role of the Federal Reserve System in preventing or ameliorating present financial crises.

\section{NONFINANCIAL CORPORATE BUSINESS}

The corporate sector is undergoing severe financial strains, but for the most part they are the result of depressed sales and lingering cost pressures. Through midyear, pre-tax profits of nonfinancial corporations have fallen by a third from their peak in the first quarter of 1981. Business failures have risen, in relative as well as absolute terms, to levels that rival the 1930-33 period. Real gross domestic product of nonfinancial corporations fell to an annual rate of $\$ 859$ billion in 1982:1 from $\$ 883$ billion a year earlier.

Because of high long-term interest rates, there has been a pronounced shift to short-term financing, leading to a greater sensitivity to market shocks. The "quick ratio" (financial assets to short-term liabilities) is at a historic low of 1.15 , and short-term liabilities are 71 percent of total liabilities. These levels, however, have not changed very much in the

7. Mortgage Bankers Association of America, "National Delinquency Survey” (August 23,1982 ), and previous issues. 
last two years. So, although interest payments consumed 39 percent of sector domestic income less employee compensation in 1982:2, an increase of 9 percent from a year earlier, substantial cash flow is still available to meet contractual obligations. These are aggregate data, of course, and many firms are in a much more tenuous position. But many types of spending can be and have been deferred. One cost of the current episode has thus been a loss of output arising from a diminished inclination to incur risks on the part of both borrowers and lenders. This is a manifestation of a crisis.

If corporate bankruptcies induce lenders to raise risk premiums, it may be a sign that new information has reached the market and proper allocative decisions are being made. For example, during 1982, ratings of many corporate bond issuers were reduced. In 1981 Moody's lowered ratings on fifty-three companies and raised them on thirty-three. As of September 30, 1982, the annualized rates have been one hundred fortyfour downgradings versus fifty-two upgradings. ${ }^{8}$ The mark of a crisis, however, would be higher risk premiums for bonds of healthy companies of a given quality - a widening of spreads between rates on corporate and Treasury bonds, for example. That would imply an increase in risk aversion, with risk premiums in excess of that required for actuarial soundness. Improper allocative decisions would result. Corporations that would have prospered, or at least survived, at the former lower level of rates (which they have merited) find themselves in greater difficulty when confronted with higher rates, thereby fulfilling the prophecy.

Bond rates for firms with less than the highest credit ratings have risen to stiff premiums over comparable issues of higher-rated corporations and the federal government, as shown in table 2 . It is interesting that the spread of the Aaa rate over long-term Treasury bonds has declined even as the Baa-Aaa spread has widened over the past several years. This may suggest a relative scarcity of the higher-rated issues as institutional investors seek to abide by rules prescribing some minimum percentage of those securities regardless of yield differences. This widening of spreads for lower-grade issuers is imposing costs on new issuers. It is true that the flow of new long-term bonds is small-Baa companies now account for about 10 percent of new issues, and bonds represent less

8. Data provided by Moody's Investors Service, Incorporated. 
Table 2. Interest Rate Differentials on Corporate Bonds, Selected Periods, 1965 through 1982:3

Percentage points

\begin{tabular}{|c|c|c|c|c|}
\hline \multirow[b]{3}{*}{ Period or quarter } & \multicolumn{4}{|c|}{ Long-term interest rate spreads ${ }^{\mathrm{a}}$} \\
\hline & \multicolumn{2}{|c|}{$\begin{array}{c}\text { Moody's corporate Aaa less } \\
\text { ten-year Treasury }\end{array}$} & \multicolumn{2}{|c|}{$\begin{array}{c}\text { Moody's corporate Baa less } \\
\text { corporate Aaa }\end{array}$} \\
\hline & Mean & $\begin{array}{l}\text { Standard } \\
\text { deviation }\end{array}$ & Mean & $\begin{array}{l}\text { Standard } \\
\text { deviation }\end{array}$ \\
\hline 1965:1-1969:4 & 0.33 & 0.18 & 0.65 & 0.18 \\
\hline 1970:1-1972:2 & 1.09 & 0.28 & 1.10 & 0.21 \\
\hline $1972: 3-1974: 2$ & 0.95 & 0.31 & 0.80 & 0.11 \\
\hline $1974: 3-1975: 2$ & 1.13 & 0.22 & 1.59 & 0.37 \\
\hline $1975: 3-1979: 4$ & 0.52 & 0.26 & 1.09 & 0.31 \\
\hline $1980: 1-1982: 3$ & 0.44 & 0.20 & 2.01 & 0.35 \\
\hline 1980:1 & 0.21 & $\ldots$ & 1.49 & $\ldots$ \\
\hline 2 & 0.80 & $\ldots$ & 2.13 & $\ldots$ \\
\hline 3 & 0.51 & $\ldots$ & 1.68 & $\ldots$ \\
\hline 4 & 0.37 & $\ldots$ & 1.93 & $\ldots$ \\
\hline 1981:1 & 0.21 & $\ldots$ & 2.01 & $\ldots$ \\
\hline 2 & 0.28 & $\ldots$ & 2.05 & $\ldots$ \\
\hline 3 & 0.17 & $\ldots$ & 1.43 & $\ldots$ \\
\hline 4 & 0.51 & $\ldots$ & 2.32 & $\ldots$ \\
\hline 1982:1 & 0.72 & $\ldots$ & 2.24 & $\ldots$ \\
\hline 2 & 0.51 & $\ldots$ & 2.11 & $\ldots$ \\
\hline 3 & 0.60 & $\ldots$ & 2.69 & $\ldots$ \\
\hline
\end{tabular}

Source: Board of Governors of the Federal Reserve System.

a. Last month of quarter.

than 25 percent of new funds raised. ${ }^{9}$ Yet these yield differentials carry over into the commercial paper and bank loan markets as well (although the spreads there are not so wide). So all corporations with lower credit ratings and a continuing need for new financing are facing higher risk premiums than before.

As in the 1970 and 1974 episodes, some firms have had their ratings lowered, but spreads are widening even between bonds of a presumably constant quality. Partly that is because the rating agencies apparently adjust ratings only when an issuer improves or deteriorates relative to the market, and not when market risk itself changes. To that extent, higher risk premiums are the result of real-sector events and are not

9. "Credit Difficulties: A Need for Perspective," The Morgan Guaranty Survey (June 1982), p. 3; and Board of Governors of the Federal Reserve System, Flow of Funds Accounts. 
products of the financial system. The yield spread on Aaa bonds is above recent levels although still narrower than during the $1970-75$ period. For bonds with lower rates, however, the spread is at an all-time high. ${ }^{10}$ These are further indications of "crisis" as defined in the previous section.

\section{MONEY MARKET MUTUAL FUNDS}

Money market mutual funds are a relatively new instrument, but already they have enormous importance. Total shares outstanding reached $\$ 225$ billion at the end of the third quarter of 1982 , of which $\$ 181$ billion was in noninstitutional funds." These accounts have grown extremely rapidly since 1979 and represent a major shift in the composition of household financial assets. For many, they have substituted for time and savings deposits (and, to a lesser extent, checkable deposits). The current crunch is the first to be encountered by the money funds, and it therefore seems appropriate to examine this industry's reaction to stress.

So far both managers and customers have prospered. Money market mutual funds enjoy an image of safety rivaling the insured depository institutions while they champion the cause of the small saver. But the very popularity of the funds-particularly to relatively unsophisticated investors-has raised questions: given the ease of withdrawals, the lack of deposit insurance, and their high visibility, is a "run" on the money funds possible? How likely is this to occur and what would the ramifications be?

One key indicator is the ability of a money fund's managers to maintain constant the net asset value of a share. This is accomplished through adroit control of default and interest rate risks.

The potential impact of defaults is minimized by purchasing highquality assets from diverse issuers. Funds typically have rigorous standards in these areas, selecting issues only from among the highest grades and avoiding undue concentration in a single issuer. Even if a

10. For a more extensive discussion of risk premiums see "Credit Difficulties," pp. 2-3.

11. Board of Governors of the Federal Reserve System, Federal Reserve Statistical Release H.6, "Money Stock Measures and Liquid Assets"' (October 8, 1982), p. 4. 
Table 3. Composition of Money Market Mutual Fund Assets, 1979 through first half of 1982

Shares of total in percent except as specified

\begin{tabular}{|c|c|c|c|c|c|c|c|c|}
\hline \multirow[b]{2}{*}{ Type of asset } & \multicolumn{4}{|c|}{ Net purchases } & \multicolumn{4}{|c|}{ Outstanding ${ }^{\mathrm{a}}$} \\
\hline & 1979 & 1980 & 1981 & $\begin{array}{l}\text { First } \\
\text { half, } \\
1982\end{array}$ & $1979: 4$ & 1980:4 & 1981:4 & $1982: 2$ \\
\hline $\begin{array}{l}\text { Certificates } \\
\text { of deposit }\end{array}$ & 22 & 31 & 21 & 6 & 26 & 28 & 24 & 22 \\
\hline $\begin{array}{l}\text { U.S. government } \\
\text { and agency } \\
\text { securities }\end{array}$ & 12 & 9 & 22 & 19 & 12 & 11 & 18 & 18 \\
\hline Open market paper & 45 & 42 & 36 & 40 & 43 & 42 & 39 & 39 \\
\hline Foreign deposits & 13 & 6 & 11 & 17 & 11 & 9 & 10 & 11 \\
\hline All other & 8 & 12 & 10 & 18 & 8 & 10 & 9 & 10 \\
\hline $\begin{array}{c}\text { Total (billions } \\
\text { of dollars) }\end{array}$ & 34.4 & 29.2 & 107.5 & $39.7^{\mathrm{b}}$ & 45.2 & 74.4 & 181.9 & 201.8 \\
\hline
\end{tabular}

default were to occur, it could be covered by earnings without affecting the share price.

Interest rate risk is minimized by the short maturities on assets that fund managers maintain as a matter of choice and as a result of Securities and Exchange Commission rules. The commission also audits money market mutual funds more frequently than other types of mutual funds.

The money market funds themselves have sought to address the issue of safety. Many new funds invest only in securites of the U.S. government and agencies. In the first quarter of 1982, these issues accounted for 38 percent of net purchases, up from 22 percent in 1981 and 9 percent in 1980. ${ }^{12}$ Bank CDs have fallen out of favor, as the funds have substantially reduced their new purchases of these instruments in 1982. The changing portfolio composition of money market mutual funds is shown in table 3 .

Is there an impact on money markets from changes in the investment attitudes of money fund managers? It may be that money funds seek to preserve their image by quickly and visibly shifting purchases in accord-

12. Board of Governors of the Federal Reserve System, Flow of Funds Accounts. 
ance with perceived preferences and not necessarily in response to actual changes in risk and return. For example, it has been reported that the money funds stopped purchasing CDs from Continental Illinois National Bank and Trust Company of Chicago after its losses in the Penn Square Bank episode came to light, even though other investors (notably other banks and overseas investors) continued to buy Continental Bank's paper at a small premium. ${ }^{13}$

Commercial paper (including finance paper and bankers' acceptances) has always represented the largest single type of asset in money market mutual fund portfolios, with the share hovering around 40 percent. Indeed, the funds have become the largest purchasers of this paper, absorbing 72 percent of the net increase in 1981, as shown in table 4 . Much of the growth in money fund holdings of commercial paper has paralleled a decline in household purchases, suggesting that many investors have simply shifted from direct purchases to use of the funds as intermediaries. Money funds plus households held 41 percent of commercial paper outstanding at the end of 1979 and hold 49 percent currently, although total paper outstanding grew during the period from $\$ 156$ billion to $\$ 247$ billion. Net new issues fell to a $\$ 31$ billion annual rate in the first half of 1982, but because of the short maturities on these instruments (generally less than six months), the stock turns over several times a year.

Now that 32 percent of outstanding paper is held by investors through money market mutual funds, does the intermediation process increase or decrease the chances of a crisis? Fewer individuals now control the decisions to roll over a larger share of outstanding paper, and they must meet the concerns of investors who can demand immediate redemption of shares. The secondary market for commercial paper is less well developed than for other money fund assets such as government securities and negotiable CDs. A decision by a few fund managers to invest elsewhere the proceeds from maturing open market paper could quickly spread to other funds. Such actions could introduce substantial shortrun disruptions as corporations seek alternative purchasers for their paper or different sources of financing.

The dollars taken out of paper would still be available for investment, either by money market mutual funds or by individual investors. A 
Table 4. Holders of Open Market Paper, 1979 through first half of $\mathbf{1 9 8 2}^{\text {a }}$

Shares of total in percent except as specified

\begin{tabular}{|c|c|c|c|c|c|c|c|c|}
\hline \multirow[b]{2}{*}{ Holder of shares } & \multicolumn{4}{|c|}{ Net purchases } & \multicolumn{4}{|c|}{ Outstanding ${ }^{\mathrm{b}}$} \\
\hline & 1979 & 1980 & 1981 & $\begin{array}{l}\text { First } \\
\text { half, } \\
1982\end{array}$ & 1979:4 & 1980:4 & 1981:4 & $1982: 2$ \\
\hline $\begin{array}{l}\text { Money market } \\
\text { mutual funds }\end{array}$ & 39 & 57 & 72 & 52 & 12 & 18 & 30 & 32 \\
\hline Households & 20 & -10 & 3 & -11 & 29 & 24 & 19 & 17 \\
\hline $\begin{array}{l}\text { Nonfinancial } \\
\text { corporations, } \\
\text { business and } \\
\text { foreign }\end{array}$ & 27 & 15 & 5 & & 38 & 35 & 28 & 28 \\
\hline Commercial banks & 5 & 8 & 1 & $\begin{array}{r}34 \\
-8\end{array}$ & $\begin{array}{l}30 \\
10\end{array}$ & 10 & $\begin{array}{r}20 \\
8\end{array}$ & 7 \\
\hline All other & 9 & 30 & 19 & 33 & 11 & 13 & 15 & 16 \\
\hline $\begin{array}{l}\text { Total (billions } \\
\text { of dollars) }\end{array}$ & 40.3 & 21.6 & 54.0 & $30.5^{\mathrm{c}}$ & 156.4 & 178.0 & 232.0 & 247.3 \\
\hline
\end{tabular}

Source: Same as table 3.

a. Commercial paper and bankers' acceptances.

b. Outstanding at end of period shown.

c. At a seasonally adjusted annual rate.

decision by the holders of funds to shift from commercial paper to bank certificates, for example, would permit a substitution by borrowers of bank loans for paper issues. The Federal Reserve would have to adjust reserves to accommodate this shift into reservable instruments, and the adjustment by borrowers and lenders would not be instantaneous, so some costs would be incurred. But none of this poses any special problems for financial markets or for the Federal Reserve.

Unlike the nonfinancial corporate sector and the depository institutions to be discussed subsequently, there are no signs of trouble stemming from the money market mutual funds. In principle, the potential does exist, however, and emerging data may indicate that money fund investment decisions tend to amplify the distortions that arise elsewhere in the system.

\section{THRIFT INSTITUTIONS}

Depository institutions may be the locus of problems in a crisis. The question is whether the difficulties of some banks or thrift institutions lead to higher borrowing costs or reduced deposit flows at institutions 
not similarly afflicted. A bank or thrift institution that finds it must pay a premium for new funds will curtail new lending. In that event, other institutions would pick up the deposits and may be able to provide the funds. But the borrower denied new credit at one bank due to a lack of funds may have difficulty arranging credit elsewhere. So the problems of banks can affect corporate spending decisions. Bank failures through the first three quarters of 1982 were triple the number for the full year 1981, and thrift industry failures are at record high levels. ${ }^{14}$

Until 1982 most problems of depository institutions (like those of the real sector) flowed from general economic conditions and not from situations arising within the financial sector. A bank that fails because it has made imprudent (or unlucky) loan decisions is not the victim of a crisis. Nor is a thrift institution that becomes insolvent as the result of a portfolio maturity imbalance with rising market interest rates. In a crunch, poorly managed institutions fail. A crisis occurs if efficient firms are pulled down because of reactions to the inefficient firms.

In the current financial crunch, unprecedented numbers of savings institutions have failed, although the ripple effects have so far been comparatively small. Doubt has been cast on the reliability of federal deposit insurance. Major changes have occurred in the retail deposit and mortgage loan markets, adding to the fragility of the system.

Thrift institutions continue to experience deposit outflows, partly because of higher rates offered elsewhere, but also because of comparable accounts at commercial banks. Deposit losses in 1981 and 1982 averaged nearly $\$ 3$ billion per month for savings and loan associations and mutual savings banks combined. ${ }^{15}$ Even on the new ninety-one day certificate, with which thrift institutions enjoyed a 25 -basis point rate advantage until September 1982, commercial banks have garnered more than half the funds. This "quiet run" appears to date from the beginning of 1981 and has had numerous consequences.

The thrift industry's cash flow had deteriorated to such a great extent by late 1981 that fears were raised about the stability of the industry. The quiet run could develop into a large-scale flight. The Federal Reserve System might be called upon to provide massive amounts of liquidity. But while the problems have continued, the process has been orderly.

14. Unpublished data from the Federal Deposit Insurance Corporation and the Federal Home Loan Bank Board.

15. Federal Home Loan Bank Board and National Association of Mutual Savings Banks. 
Thrift institutions, once the major source of new mortgage funds, have been net sellers of mortgages for the past few quarters. Mortgage pools assembled by Ginnie Mae, Fannie Mae, and Freddie Mac ${ }^{16}$ have been major suppliers of funds, increasing the amount of "governmentrelated" debt. Furthermore, the lost deposits at savings and loan associations have been partially replaced by advances from the Federal Home Loan Bank System. These advances, nominally for "liquidity" purposes, totaled $\$ 67$ billion by mid-1982, ${ }^{17}$ suggesting that governmentraised funds are becoming an important source of permanent financing for savings and loans. As a result of reduced mortgage lending activity and increased borrowing, savings and loan associations have substantially improved their liquidity from a low point in the first half of 1981 . Cash flow plus liquid resources now equal 156 percent of potential exposure to cash outflows, compared with the 112 percent of 1981, but still below the 201 percent of early 1980 .

The decline in short-term rates since midyear is welcome news to beleaguered savings and loan associations and mutual savings banks because two-thirds of their deposits have rates tied to short-term Treasury instruments or bank CDs. ${ }^{18}$ Savings and loans had operating losses after tax at an annual rate of $\$ 6.6$ billion in the first half of 1982 , compared with $\$ 4.6$ billion for all of $1981 .^{19}$

In an earlier work I analyzed the earnings outlook for the thrift industry under alternative interest rate scenarios. ${ }^{20}$ At that time I expected about 1,100 thrift disappearances, roughly half of which would be involuntary transactions (supervisory and assisted mergers and liquidations) arranged by the Federal Savings and Loan Insurance Corporation (FSLIC) and the FDIC. Many of these combinations will require financial assistance from the regulatory agencies to protect insured deposits. The earlier projections anticipated that the cost of this aid would nearly deplete the insurance reserves of the FSLIC.

New projections confirm the earlier results. Even the dramatic decline in short-term interest rates that has occurred and that is projected does

16. The Government National Mortgage Association, Federal National Mortgage Association, and Federal Home Loan Mortgage Corporation, respectively.

17. About 10 percent of total liabilities.

18. Federal Home Loan Bank Board, "Savings and Loan Activity in June," News (August 2, 1982), table 1.

19. Unpublished data from the Federal Home Loan Bank Board.

20. Andrew S. Carron, The Plight of the Thrift Institutions (Brookings Institution, 1982). 
not arrest the deterioration in the industry's net worth. Operating losses will continue as the average cost of liabilities rises to market levels, indicating a continuation of involuntary mergers with financial assistance provided by the FSLIC. Implementation of title II of the Garn-St. Germain Depository Institutions Act of 1982, which calls for additional expenditures by the FSLIC to ongoing firms, might be expected to increase the costs even further. But the agency has become increasingly resourceful in minimizing the reported expenses associated with its assistance programs. The FSLIC will issue interest-bearing securities to troubled institutions in exchange for income-capital certificates, debtequity hybrids that require interest (dividend) and principal payments only if net operating income is positive. Because these certificates will be carried by the FSLIC at book value, the transaction has no immediate effect on the agency's reported condition. The economic cost has increased but accounting costs have not. It now appears that noadditional resources will be required as long as interest rates do not rise substantially and confidence in the regulators is maintained.

Government agencies have been successful so far in relieving the pressures on the thrift industry. There are indications, however, that the limits are being approached on FSLIC and FDIC merger assistance, Federal Home Loan Bank System lending, tax credits, purchase accounting in supervisory mergers, and the other techniques that have been used until now. Without the decline in short-term rates, the pace and cost of thrift institution failures might have overwhelmed the administrative, legal, and financial capabilities of the regulatory agencies. In the event of a widespread loss of confidence in the thrift institutions, the Federal Reserve System would be called upon to provide the liquidity to cover withdrawals; at that point, the Federal Reserve would find itself holding collateral of low liquidity and uncertain value, with little prospect of soon reversing the transactions. It may be that the Federal Reserve viewed its choices at midyear as being monetary ease then or later. It chose the more orderly approach, acting promptly.

INTERNATIONAL LENDING AND THE COMMERCIAL BANKS

Conditions in the United States concern other countries as well. Developing countries have been particularly hard hit by the reduced 
Table 5. Bank Debt of Selected Developing Countries, End of Year 1981 Billions of dollars

\begin{tabular}{|c|c|c|c|c|}
\hline \multirow[b]{2}{*}{ Country } & \multicolumn{2}{|c|}{ Total bank debt } & \multicolumn{2}{|c|}{ Short-term debt $t^{\mathrm{a}}$} \\
\hline & All banks & U.S. banks & All banks & U.S. banks \\
\hline Mexico & 56.9 & 21.5 & 24.0 & 12.6 \\
\hline Brazil & 52.7 & 16.8 & 14.3 & 7.7 \\
\hline Argentina & 24.8 & 8.4 & 9.9 & 5.2 \\
\hline South Korea & 19.9 & 8.9 & 10.6 & 6.5 \\
\hline Subtotal $^{\mathrm{b}}$ & 154.3 & 55.6 & 58.8 & 32.0 \\
\hline All others & 85.5 & 37.2 & 56.8 & 24.0 \\
\hline Total $^{\mathrm{b}}$ & 239.8 & 92.8 & 115.6 & 56.0 \\
\hline
\end{tabular}

Source: John Calverley, "How the Cash Flow Crisis Floored the LDCs," Euromoney (August 1982), p. 32; Federal Financial Institutions Examination Council, Statistical Release E.16, "Country Exposure Lending Survey" (June 3, 1982); and author's estimates.

a. Debt with original maturity of one year or less.

b. Totals may not add due to rounding.

demand for their exports and the higher cost of dollars needed to pay for imported oil. These developments have impaired their ability to make scheduled payments on outstanding bank loans. ${ }^{21}$ In turn, this has raised the prospect of a domestic financial crisis developing from a default on loans by U.S. banks to sovereign borrowers. Two questions need to be considered: which debts are large enough to cause a major impact; and, among those, what are the chances of default?

A small number of sovereign borrowers account for the majority of the outstanding debt. Among developing countries that are not major oil exporters, a category that includes Mexico, four nations-Argentina, Brazil, Mexico, and South Korea-owe 64 percent of the $\$ 240$ billion in total bank debt, as shown in table 5. U.S. banks are heavily involved in this lending. They hold more than a third of the loans to nonoil developing countries, including the four large borrowers just mentioned.

U.S. banks play a much smaller role in loans to Eastern Europe, where Poland, the U.S.S.R., East Germany, and Hungary are the major borrowers. The external bank debt of the Eastern Bloc is only $\$ 71$ billion, and U.S. banks hold only a small fraction of the total. So, despite the well-known problems in Poland, U.S. bank exposure to major risks appears confined to the developing countries just mentioned.

21. Robert Solomon, "Is a Debt Crisis Likely?"' International Economic Letter, vol. 2 (July 15, 1982). 
How well, then, are these countries coping with their debt? An indication can be gained from comparing export earnings with debt service. And whatever conclusions are to be drawn must also take account of recent policy actions that will improve or worsen the situation.

South Korea's debt does not appear to be a problem. That nation has a growing economy with substantial export earnings, and it now enjoys a credit rating rivaling the most favored sovereign borrowers. Recent loans to Korea have carried interest rates slightly lower than the average for OECD borrowers.

The three large Latin American nations clearly present the major problems, both for international bank lending in particular and for the financial system in general. Mexico appears to be the biggest problem at the moment, but Brazil and Argentina also have difficulties ąnd together their debt to U.S. banks exceeds that of Mexico.

The risks in Mexico were thought to be low because that country is an oil exporter. This source of strength faded with declines in the demand for and price of oil. Its trade deficit grew, inflation increased, and the currency was devalued. Mexico's interest payment burden was projected to be a high 34 percent of exports in 1982, with principal payments equal to 85 percent of exports falling due also. ${ }^{22}$ By late 1981 , lenders began to demand higher interest rates. Eurodollar loans to Mexican sovereign borrowers carried a premium of 0.5 percentage point over the London Interbank Offered Rate (LIBOR) early in 1981, but the rate increased to 1.5 points over LIBOR for the last new loans negotiated in 1982:2 (see figure 1). The few small medium-term credits issued in the third quarter carried premiums of 2 points over LIBOR. Finally, the government of Mexico announced that it would be unable to make timely payment of interest and principal on the outstanding bank loans, and it sought assistance from the U.S. government and international agencies.

A major concern has been the effect of the Mexican problems on the U.S. banks that hold $\$ 22$ billion of those loans. Even if most or all the loans will ultimately be repaid, their present discounted value will be reduced, but by amounts that cannot be calculated with precision. The amounts will depend on current account dynamics, the amount of new infusions of capital and maturity extensions required, and actions by the oil-exporting cartel. This uncertainty is a major part of the problem.

22. Morgan Guaranty Trust Company of New York, World Financial Markets (August 1982), p. 10. 
Figure 1. Average Loan Rate Spreads over LIBOR, Selected Countries, 1979:1 through 1982:2

Percentage points

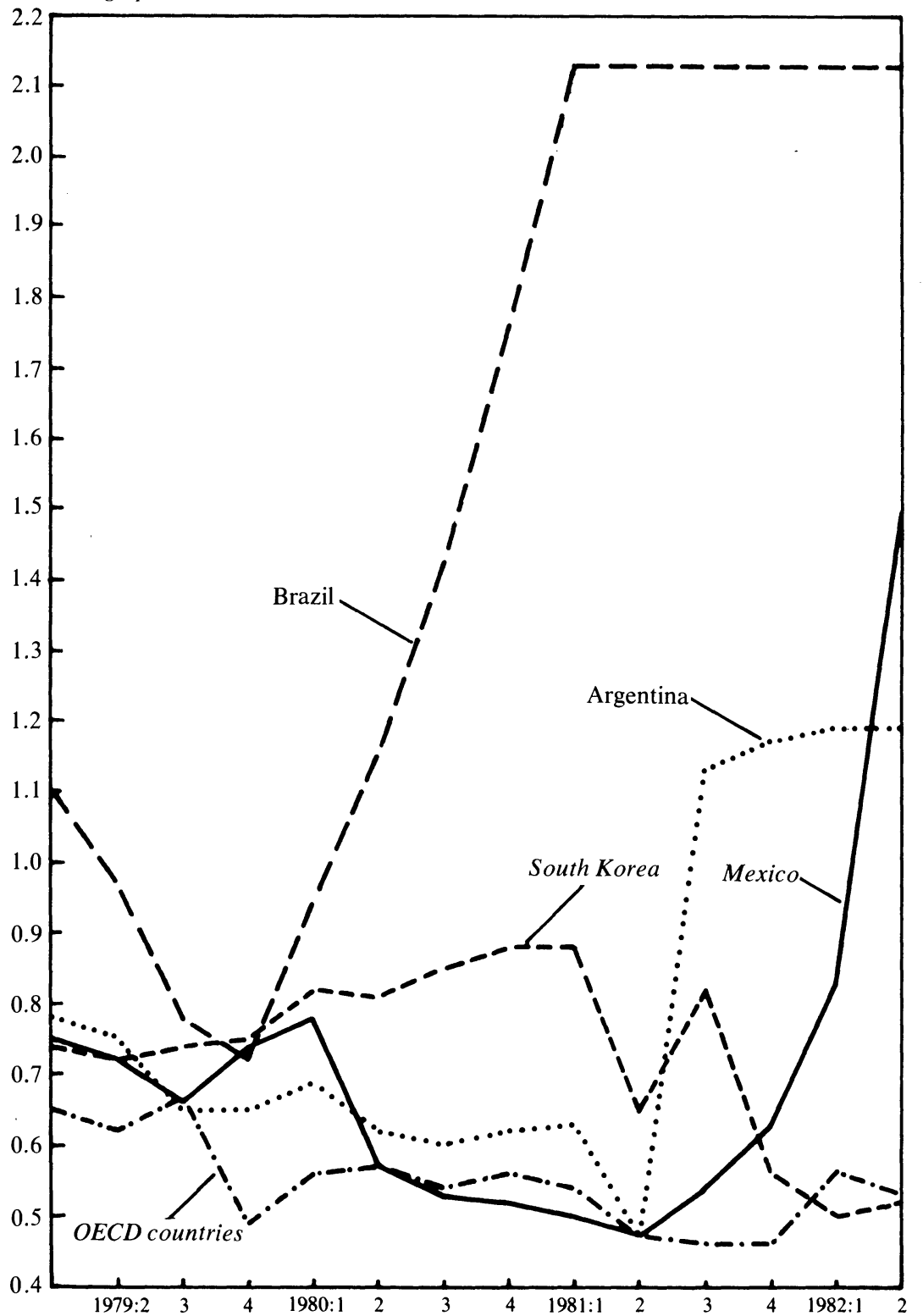

Sources: Data for the OECD spreads are from Organization for Economic Cooperation and Development, Financial Market Trends (Paris: OECD, June 1982), and previous issues. Data for individual LDCs were provided by Morgan Guaranty Trust Company of New York. 
Table 6. U.S. Bank Exposure to the External Debt Problems of Mexico, End of Year 1981

\begin{tabular}{lcccc}
\hline \multicolumn{1}{c}{ Bank $^{\mathrm{a}}$} & $\begin{array}{c}\text { Amount } \\
\text { owed } \\
\text { to bank } \\
\text { (billions } \\
\text { of dollars) }\end{array}$ & $\begin{array}{c}\text { Total } \\
\text { capital } \\
\text { of bank } \\
\text { (billions } \\
\text { of dollars) }\end{array}$ & $\begin{array}{c}\text { Amount } \\
\text { owed as } \\
\text { share of } \\
\text { capital } \\
\text { (percent) }\end{array}$ & $\begin{array}{c}\text { Capital } \\
\text { as share } \\
\text { of assets } \\
\text { (percent) }\end{array}$ \\
\hline Manufacturers Hanover & 1.4 & 2.3 & 61 & 4.2 \\
Bank of America & 2.5 & 4.6 & 54 & 3.9 \\
First Chicago & 0.6 & 1.3 & 46 & 4.0 \\
Bankers Trust & 0.7 & 1.6 & 44 & 4.7 \\
Chemical Bank & 1.0 & 2.2 & 45 & 4.8 \\
Citibank & 2.3 & 5.3 & 43 & 5.1 \\
Chase Manhattan & 1.6 & 4.2 & 38 & 5.5 \\
Morgan Guaranty & 0.9 & 2.6 & 35 & 4.9 \\
Continental Illinois & 0.6 & 2.0 & 30 & 4.5 \\
All reporting banks & & & & \\
$\quad$ Nine money center banks & 11.8 & 26.1 & 45 & 4.6 \\
Fifteen other large banks & 4.4 & 12.2 & 36 & 5.2 \\
All other reporting banks & 5.6 & 24.4 & 23 & 6.7 \\
\multicolumn{1}{c}{ Total of all reporting banks } & 21.8 & 62.7 & 35 & 5.4 \\
\hline
\end{tabular}

Sources: Federal Financial Institutions Examination Council, Statistical Release E.16 for all data except that on loans of individual money center banks, which are author's estimates based on "Worry at the World's Banks," Business Week (September 6, 1982), p. 82.

a. Banks listed in order of decreasing loan-to-capital ratio.

b. Total amounts owed U.S. banks by Mexican borrowers (except peso loans) after adjustments for guarantees and external borrowing.

c. Equity capital, subordinated notes, and reserves.

d. First National Bank of Boston, Marine Midland Bank, The Bank of New York, Irving Trust Company, Mellon Bank, National Bank of Detroit, First National Bank in Dallas, Republic Bank Dallas, First City National Bank of Houston, Security Pacific National Bank, First Interstate Bank of California, Crocker National Bank, Wells Fargo Bank, Seattle-First National Bank, and Texas Commerce Bank.

Bankers and regulators fear the indirect effects of the Mexican situation on depositor confidence and regulatory standards. If buyers of jumbo CDs shun certain banks, the ensuing liquidity shortage would call for intervention by the Federal Reserve. And classification of the Mexican loans as nonperforming could subject some banks to increased government supervision and restrictions on their activities. Formal declaration of default could reduce the capital of a few banks below the regulatory minimum.

The exposure and condition of U.S. banks is shown in table 6. For the nine money center banks, the outstanding Mexican loans are equal to 45 percent of capital. The average for other U.S. banks is considerably lower. Even if the write-downs on Mexican loans are relatively small, 
when added to the losses experienced by several banks on domestic loans a substantial share of capital is seen to be at risk. Once capital is exhausted, losses fall on uninsured creditors including holders of jumbo CDs. It is this possibility that concerns investors and bankers. A few large banks with large Mexican exposures are now paying premiums over the $\mathrm{CD}$ rates paid by money center banks that are less heavily involved in international lending. Moreover, Mexico is not the only large sovereign borrower in trouble.

Brazil's interest burden exceeds one-third of its total export earnings, and amortization payments are an equally large amount, the highest of all countries under consideration. ${ }^{23}$ Oil imports and depressed export markets are primarily to blame. Yet that nation, through tight monetary policy, has slowed imports to create a trade surplus and moderate its current account deficit. If this effort continues, despite the social and political difficulties that it creates in Brazil, no crisis is anticipated. ${ }^{24}$ Nonetheless, lenders have demanded stiff premiums for new Brazilian credits. Several new loans this year carried a spread of $2 \frac{1}{8}$ percentage points over LIBOR, a penalty higher than that demanded of all but a few very poor nations ${ }^{25}$ If a default did occur, however, it could have serious implications for U.S. banks. The U.S. bank debt of Brazil is equal to 39 percent of the net worth of the twenty-four largest U.S. banks. Even though the holdings of Brazilian debt are not so heavily concentrated as holdings of Mexican debt, some banks could have serious difficulties in the event of a default.

Argentina's external debt is half that of Brazil or Mexico, and until recently its export earnings represented greater interest coverage than either of these two. The Falkland Islands conflict injected great uncertainty into the Argentine economy, reducing exports, depressing the currency, and raising the import bill for such items as weapons and fuel. Few new loans have been made to Argentine government-backed borrowers since the crisis, so it is unclear what probabilities lenders place on a moratorium or default. Spreads have increased sharply from 0.6 percentage point over LIBOR in 1981:2 to 1.2 points premium in

23. Ibid.

24. Lawrence B. Krause, "International Economic Comment: Debts of Developing Countries and their Impact on the World Economy," Economic Research (Goldman Sachs, December 4, 1981), pp. 1-6; and Solomon, "Is a Debt Crisis Likely?" pp. 7-9.

25. Unpublished data from Morgan Guaranty Trust Company. 
1982:2. A rescheduling of Argentina's debt appears quite likely. The risks are substantial in Argentina but the exposure is the smallest of the major borrowers.

Thus far commercial banks are weathering the current adversity. Deposit flows are healthy, with retail deposits at banks growing faster in 1982 than even money market mutual fund shares. ${ }^{26}$ Nonperforming assets at major banks have increased to 2.2 percent of total loans and nonperforming real estate this year, from 1.8 percent in 1981 and 1.5 percent in $1980 .{ }^{27}$ Continental Illinois National Bank has stated that its nonperforming loans are now at 5.7 percent of assets. ${ }^{28}$ Otherwise, these levels are still below the 5 percent or more of assets represented by nonperforming loans in the aftermath of the 1974-75 recession. ${ }^{29}$

Another measure of the problems of the commercial banks can be found in the interest rate spreads on large CDs. Although rates have been quite volatile, the spread between CDs and Treasury bills hovered in the range of 50 basis points for much of the last year. In July, the spread began to widen as Treasury rates led the market downward. By mid-August, concerns over pressures on the banking sector led initially to a rise in the CD rates as the Treasury bill rate continued to drop. With further declines in both rates through late August, the spread reached nearly 200 basis points-above earlier levels ( 27 basis points average over 1975-79) but still below the spreads recorded after the Franklin National Bank failure in 1974 (see table 7). By mid-September, however, the spread was around 250 basis points-comparable to the 1974-75 recession. Investor uncertainty is affecting all banks, even as some distinctions are being made on the basis of exposure to international risks. So there are indications of crisis conditions among the commercial banks.

\section{ROLE OF THE FEDERAL RESERVE}

The Federal Reserve has been seen to play two roles in the development and resolution of financial market difficulties. As an inflation fighter it has the power to induce stresses in the real sector that can lead to

26. Federal Reserve Statistical Release H.6, p. 4.

27. Morgan Guaranty Trust Company.

28. New York Times, October 15, 1982.

29. "Credit Difficulties," pp. 1-2. 
Table 7. Interest Rate Spreads on Bank Certificates of Deposit, Selected Periods, 1974 through 1982:3

Percent

\begin{tabular}{|c|c|c|c|}
\hline Period & $\begin{array}{l}\text { Bank three-month } \\
\text { jumbo CD rate }\end{array}$ & $\begin{array}{l}\text { Three- } \\
\text { month } \\
\text { Treasury } \\
\text { bill yield }\end{array}$ & Spread \\
\hline \multicolumn{4}{|c|}{ Last month of quarter } \\
\hline $1974: 1$ & 8.84 & 8.49 & 0.35 \\
\hline 2 & 11.38 & 8.43 & 2.95 \\
\hline 3 & 11.60 & 8.61 & 2.99 \\
\hline 4 & 9.23 & 7.59 & 1.64 \\
\hline $1975-79$ & 7.36 & 7.09 & 0.27 \\
\hline 1980:1 & 17.57 & 17.02 & 0.55 \\
\hline 2 & 8.49 & 7.50 & 0.99 \\
\hline 3 & 11.29 & 11.13 & 0.16 \\
\hline 4 & 18.65 & 17.38 & 1.27 \\
\hline 1981:1 & 14.43 & 14.77 & -0.34 \\
\hline 2 & 16.90 & 16.44 & 0.46 \\
\hline 3 & 16.84 & 16.40 & 0.44 \\
\hline 4 & 12.49 & 11.80 & 0.69 \\
\hline 1982:1 & 14.21 & 13.96 & 0.25 \\
\hline 2 & 14.46 & 13.71 & 0.75 \\
\hline 3 & 10.66 & 8.45 & 2.21 \\
\hline \multicolumn{4}{|c|}{ Week ending } \\
\hline \multicolumn{4}{|c|}{ July } \\
\hline 2 & 15.21 & 14.11 & 1.10 \\
\hline 9 & 14.80 & 13.32 & 1.48 \\
\hline 16 & 13.96 & 12.81 & 1.15 \\
\hline 23 & 12.58 & 11.56 & 1.02 \\
\hline 30 & 12.01 & 11.40 & 0.61 \\
\hline \multicolumn{4}{|c|}{ August } \\
\hline 6 & 11.43 & 10.58 & 0.85 \\
\hline 13 & 11.63 & 10.47 & 1.16 \\
\hline 20 & 9.77 & 8.40 & 1.37 \\
\hline 27 & 9.73 & 7.97 & 1.76 \\
\hline \multicolumn{4}{|c|}{ September } \\
\hline 3 & 10.42 & 8.89 & 1.53 \\
\hline 10 & 10.58 & 8.92 & 1.66 \\
\hline 17 & 10.94 & 8.57 & 2.37 \\
\hline 24 & 10.73 & 8.01 & 2.72 \\
\hline \multicolumn{4}{|c|}{ October } \\
\hline 1 & 10.43 & 8.00 & 2.43 \\
\hline
\end{tabular}

Source: Board of Governors of the Federal Reserve System.

a. Averages of daily rates, secondary market.

b. Discount rate converted to investment yield. 
financial crises. As central banker the Board can prevent the illiquidity and restore the lost confidence that come with a crisis. These two activities may at times be inconsistent with each other. That is more true now than it was before innovation demolished many of the barriers between financial markets and institutions.

The task of the Federal Reserve is to balance these roles. Until this summer, monetary restraint took precedence and a financial crunch ensued. From the Federal Reserve's point of view, this was entirely appropriate as long as there was no crisis. But then came the first signs of a developing crisis-widening corporate bond spreads, the possible collapse of the thrift industry, and tremors in the international banking system.

Nearly every measure developed here suggests a crisis in the financial sector. The magnitude of the distress is roughly comparable to the 197475 recession, although some parts of the system are in a better condition than they were during the earlier episode while others are worse. Failures among the manufacturing, banking, and thrift industries are substantially above postwar peaks. On the other hand, nonperforming loans at banks and the excess premiums paid by banks for CDs are at levels below those of 1974-75.

The 1974-75 recession exposed the financial system to enormous strains. Many observers believed that the eventual recovery was quite fortuitous. That earlier experience may indicate the limit to which the system can safely be pressed. It may be inferred that the warning signs observed in mid-1982 induced the Board to revise its stance. This suggests that the Federal Reserve views the efficiency of the financial system as its primary responsibility-its role as central banker.

This is good news for those who fear the consequences of a financial crisis per se or who view the misallocations that result as too high a price to pay for the possible further moderation of inflation. It appears that monetary policy has been controlled so as to force the economy through a financial crunch into the early stages of a crisis. But that is as far as the Federal Reserve seems willing to go. 


\section{Comments and Discussion}

Benjamin M. Friedman: I found the parts of Andrew Carron's paper that explained and documented what has been happening much more helpful than the attempts to develop categories for different degrees of financial problems and thereby to define a "financial crisis." I doubt that we will ever be able to draw such distinctions well. Carron makes as good an attempt as I have seen, but still the resulting definitions are not very satisfying.

I would like to discuss some of the paper's conclusions. I agree with Carron that the higher-risk premiums that we have seen on risky securities in the financial markets to date have had to do almost entirely with the discounting of risks associated with real phenomena. The markets are now realizing that our economy is simply not going to have a typical vigorous recovery from the current recession, and moreover that unemployed workers are not the only economic actors to be hurt in such a situation.

There was a long period during which participants in the market were apparently able to persuade themselves either that disinflation was going to be costless or that the only people who had to pay the costs were on the unemployment line. That view is now disappearing, and market participants are starting to understand something that Carron's paper brings out well: if the economy has a recession like the current one, which has been the worst yet in the postwar period from the perspective of business profits, and then does not follow it with a strong recovery, the resulting situation is ruinous for many firms.

Carron has documented the position of the thrift industry very well, and he has identified the basic problem: the FSLIC just does not have 
enough capital to keep the thrift industry operating with its current structure intact.

I would therefore urge that bank mergers with thrift institutions be more actively encouraged as a way out of the present problems of the thrifts. The banking system provides an obvious pool of capital for this purpose. For banks want to enter diverse markets, especially across state lines, and it seems entirely in order to let them pay for that relaxation of currently prevailing restrictions. The way to let the banks do so is through assumptions of essentially failed thrift institutions. I see no reason to put the taypayers' money into saving the thrift institutions when banks are willing to put in their capital instead.

Finally, Carron appears more concerned than I would be about the prospect that banks with foreign loans would have to take losses on these loans. To some degree the banks have put themselves in this situation. Those banks that are at greatest risk are the ones that have been the most aggressive in asserting that these loans were not risky. In fact they were risky. These banks have not been putting aside adequate loan loss reserves and therefore have been overstating their earnings for years.

In some cases, it almost appears to be a deliberate policy on some banks' part to buy enough high-risk loans to convert them into zero-risk loans by creating a position in which the U.S. government will have to bail them out in the end.

My conclusion is that, although a situation in which banks fail should and can be avoided, we should not be determined to avoid losses to shareholders in banks that have pursued such policies. If some of these loans were written down as nonperforming, and banks therefore had to raise new capital at low equity prices, that would only reflect the true result of the lending policies they have chosen.

\section{General Discussion}

Robert Hall elaborated on the paper's analysis of money market funds by pointing out their significant advantage compared with commercial banks in terms of financial crisis risks. According to Hall, the banking system is especially prone to crises because banks give depositors a face-value claim rather than an equity claim on the banks' assets. If banks gave equity claims, as funds do, there could be no question of the 
banks failing or become illiquid because of a few problem loans. Depositors would find that the value of their claims had declined as a result of the problems, but would have no temptation to withdraw all their assets immediately. Jeffrey Sachs replied that, even though bank failures as such would not be a problem, the system of international lending might not be more stable if depositors had equity stakes. He observed that the last great crisis in international credit markets occurred in 1931 when banks did not play a central role. Almost all foreign lending in that era was in the form of bonds, an asset much closer to current money market holdings than to bank deposits. Sachs argued that institutional bank lending in the international market has greatly enhanced the efficiency of international lending because, in the present era, banks can flexibly negotiate with creditors to reschedule debt payments. Debt rescheduling is sometimes tantamount to partial default, but is far less disruptive than the formal defaults and unilateral debt moratoria which were so common before 1930. James Tobin added that the present arrangement, at least since its reform in 1935, has not done that badly. It seems to perform well in the allocation of risk and maturity preference and in providing intermediation. Through this process banks create liquidity and safety that depositors want and need and that would be absent in a world of nothing but funds in which depositors are forced to bear equity risks.

Robert Solomon strongly disagreed with the suggestion in Benjamin Friedman's comment that large commercial banks with international problem loans should be compelled to pay all the losses associated with these loans. He disagreed with Friedman's premise that these loans were reckless, and argued instead that most of the present problem is attributable to unprecedentedly high real interest rates and the recession in the industrial countries-factors not under the control of either the large banks or their LDC customers and developments that were well beyond the range of normal expectations. He also argued that, if the large banks were compelled to reduce their international lending, the impact on the less developed countries and, in turn, on the industrial countries, would be severe.

Peter Kenen expanded on the current risk of a country defaulting in the international credit market. He argued that the risk of full default is quite small and that debt reschedulings do not normally affect the net worth of lenders. Bank examiners do not reclassify rescheduled loans 
as "nonperforming" for fear of adversely affecting the banks' capacity to participate in debt reschedulings. Kenen also remarked that banks currently have a great deal of indirect exposure to international risks. Banks that have not directly lent to Mexico or Poland, for example, may be indirectly affected by those countries' problems because of loans to banks in third countries that in turn have supplied credit to Mexico or Poland. 